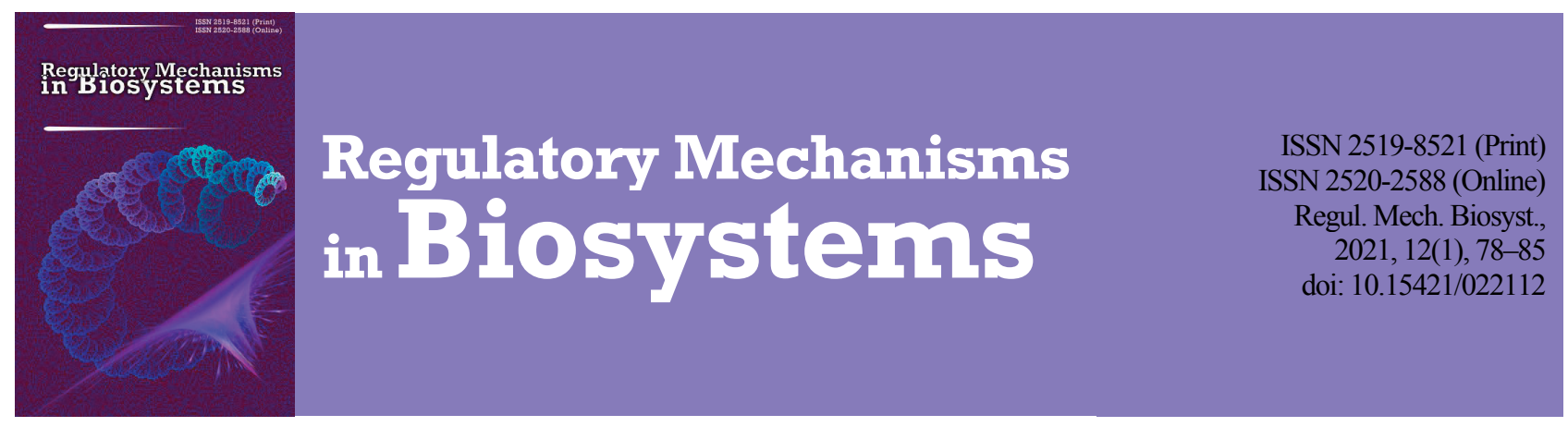

\title{
The synthesis of lipids and proteins in vitro in tissues of Cyprinus carpio infected with Bothriocephalus acheilognathi
}

\author{
L. L. Yuskiv, I. D. Yuskiv \\ Stepan Gzhytskyj Lviv National University of Veterinary Medicine and Biotechnologies, Lviv, Ukraine
}

Article info

Received 14.02.2021

Received in revised form 10.03.2021

Accepted 11.03.2021

\begin{abstract}
Yuskiv, L. L.,\& Yuskiv, I. D. (2021). The synthesis of lipids and proteins in vitro in tissues of Cyprinus carpio infected with Bothriocephalus acheilognathi. Regulatory Mechanisms in Biosystems, 12(1), 78-85. doi:10.15421/022112
\end{abstract}

Stepan Gzhytskyj Lviv National University of Veterinary Medicine and Biotechnologies, Pekarska st. 50, Lviv, 79000, Ukraine. Tel.: +38-063-223-36-22. E-mail: igor_yuski@@ukr.net

Rivne State University of Humanities, Stepan Bandera st., 12, Rivne, 33028, Ukraine. Tel.: +38-098-259-37-57. E-mail: irchukmail@gmail.com

The problem of the mechanisms of regulation of biochemical processes in carp Cyprinus carpio (Linnaeus, 1758) tissues and organs caused by infection with Bothriocephalus (Schyzocotyle) acheilognathi (Yamaguti, 1934) at different intensities of invasion remains practically unstudied. The purpose of this study was to dedetrmine the intensity of lipid and protein synthesis in vitro when $\left[6-{ }^{14} \mathrm{C}\right] \mathrm{glucose}$ and $\left[2-{ }^{14} \mathrm{C}\right]$ lysine are used as their precursor in the tissues of the intestine, hepatopancreas and skeletal muscles of carp. The study was conducted on this-year carp with body weight 14.5-20.5 g, at different invasion rates of the helminth B. acheilognathi, which belongs to the family Bothriocephalidae of the Pseudophyllidae order of the Cestoda class of the Plathelminthes phylum. The examined carp were divided into three groups: 1st group of fish was free from intestinal helminths of B. acheilognathi (control); 2nd group of fish was weakly infected with helminths (intensity of invasion was 1-3 helminths per fish); the 3rd group of fish was highly infected (the invasion intensity was 4 worms and more per fish). Our results showed that in fish infected with the helminth B. acheilognathi in comparison to uninfected, the intensity of lipid synthesis in the intestinal wall, hepatopancreas, skeletal muscle was much lower when $\left[6-{ }^{14} \mathrm{C}\right]$ glucose was used as a predecessor than when $\left[2-{ }^{14} \mathrm{C}\right]$ lysine was used as a predecessor. In the examined tissues, significant decrease was observed in the synthesis of reserve lipids (mono-, di- and triacylglycerols) in comparison to the structural (phospholipids and cholesterol), which depends on the intensity of the B. acheilognathi invasion. In the metabolic processes in the wall of the intestine, hepatopancreas, skeletal muscle of thisyear carp infectd with $B$. acheilognathi helminths, under in vitro conditions, $\left[6-{ }^{14} \mathrm{C}\right]$ glucose was used more than $\left[2-{ }^{14} \mathrm{C}\right] \mathrm{lysine}$. The intensity of protein synthesis in the intestinal wall, hepatopancreas, skeletal muscles of this-year carp infected with the helminth B. acheilognathi under in vitro conditions increased when $\left[6-{ }^{14} \mathrm{C}\right]$ glucose was added to the incubation medium, on average $7.1-28.3 \%$ and decreased when $\left[2-{ }^{14} \mathrm{C}\right]$ lysine was added, on average $7.8-25.7 \%$.

Keywords: intestine; hepatopancreas; skeletal muscle; metabolism; synthesis; fish.

\section{Introduction}

The Asian fish tapeworm Bothriocephalus (Schyzocotyle) acheilognathi (Yamaguti, 1934) (Cestoda, Bothriocephalidea) was first identified in Acheilognathus rhombeus in Lake Ogura (Japan). Today, B. acheilognathi is spread on all the continents (except Antarctica), including isolated islands (Hawaii, Puerto Rico, Cuba, Sri Lanka, Madagascar) and adapted to the physiological conditions of the intestine of 312 species of freshwater fish (Kuchta et al., 2008; 2018). The resulting disease is usually chronic and characterized by partial or complete intestinal obstruction by $B$. acheilognathi helminths, inflammation of the mucous membrane, malfunctioning of metabolism and energy metabolism, and poisoning of the fish with helminthotoxins (Scholz et al., 2012; Ahmad et al., 2018). The helminth B. acheilognathi is pathogenic not only at high intensity of invasion, but also at insignificant level of invasion - 1-3 helminths per fish (16.0 $19.0 \mathrm{~cm}$ long), which manifests in notable decrease in live weight and coefficient of fattening, and as a consequence, negatively affects their survival in winter due to the reduction of metabolic energy reserves in the body in the form of reserve lipids and proteins (Yuskiv, 2006; Yuskiv \& Yuskiv, 2020).

Lipids play an important role in the body's response to exogenous and endogenous factors, due to their role in the energy and signal systems of the cell (Hrytsyniak et al., 2010). Lipids are important components that are involved in the building of cell membranes, nuclei and mitochondria and they play a major role in the functioning and course of various processes in cells (Deb, 2011; Al-Niaeemi \& Dawood, 2017).
Fish receive lipids from their diet and absorb them in the forms of fatty acids and triacylglycerols, which are transformed into chylomicron particles (Sheridan, 1988; Tao et al., 2018). In the liver, lipids and fatty acids that come from the digestive tract are synthesized and converted into compounds characteristic of the tissues of the body of fish. Fish store lipids in various organs, including the mesenteric membrane, liver, and muscles (Sheridan, 1988; Hrytsyniak et al., 2010; Pastorino et al., 2020).

The accumulation of lipids in the liver is regulated by biochemical mechanisms: by reducing the supply of lipids to the liver, increasing the absorption of circulating fatty acids by the liver, reducing beta-oxidation of fatty acids and increasing their synthesis in the liver (Sheridan, 1988; Tao et al., 2018).

When the water temperature decreases, the activity and food consumption of fish slows down. During this condition, metabolic processes in their bodies are enhanced by increased use of lipids, as evidenced by the lower percentage of lipids in the liver during the winter months as compared with summer.

The accumulation of lipids in the liver is an adaptive process and an important factor in the survival of fish in winter (Hrytsyniak et al., 2010; Pastorino et al., 2020). Therefore, the deposition and usage of lipids in fish is an adaptive response that is characteristic of poikilothermic organisms to prevent lower metabolism during winter starvation and at different stages of life due to abiotic and biotic factors (Fernandes \& McMeans, 2019).

The lipids that are released from liver can be transported in the blood as fatty acids bound to the corresponding proteins (Sheridan, 1988). During the starvation, the fish's body uses its own reserves. In such condi- 
tions, fats are also introduced from the adipose tissue and transferred to the liver and then transformed into acetyl-CoA as a result of $\beta$-oxidation and used for the needs of the body.

Lipid metabolism in the liver is closely related to the metabolism of carbohydrates and amino acids. Therefore, during prolonged starvation, liver and muscle protein is used for metabolic energy (Shimeno et al., 1990). This data indicate that glycolysis, lipogenesis and energy production are significantly reduced during hunger, while gluconeogenesis and the use of amino acids remains the same and further provides the hepatopancreas with glucose. In addition, during prolonged hunger after the use of glycogen, fish use as lipids and protein as sources of energy in the body (Shimeno et al., 1990).

The various factors of exogenous- and endogenous-nature change the direction and nature of protein metabolism in fish. The norm of vital activity of an organism of fish is the existence of reserve systems that are able to compensate for changes in metabolic rate, which occur during various physiological loads or pathological processes (Dogan, 2008; Meyer-Burgdorff \& Rosenow, 2009). This is caused by the presence of proteins in some tissues of fish, in particular in the hepatopancreas and skeletal muscle, which perform a structural and reserve function in the body and are used to satisfy their need for metabolic energy under stress caused by environmental factors and invasive diseases, and thus affect their survival (Li et al., 2009; Kurovskaya \& Strilko, 2016).

In normal conditions, the bulk of fish tissue proteins are formed by amino acids that enter the bloodstream from the digestive tract. In fish, the proportion of amino acids only in the substrate energy metabolism may account for 32-86\%, while carbohydrates range 10-36\% (Gilannejad et al., 2018). During hunger or deficiency of essential amino acids, the main source of nitrogenous substances comprise the products of enzymetic cleavage of blood proteins (Schutz, 2010).

The proteins in fish tissues are constantly refreshed, and the rates of these processes depend on the rates of their synthesis and breakdown. Experiments on carp have shown that in in vitro conditions when using $\left[2-{ }^{14} \mathrm{C}\right]$ lysine, in fish of the age of one to two years, the protein content in the skeletal muscle increased 1.9 times, and at the age of second to third year - decreased 1.5 times (Pylypets \& Yanovich, 2000). The radioactivity of protein synthesized by skeletal muscle sections of carp incubated with $\left[6-{ }^{14} \mathrm{C}\right]$ glucose was about $10 \%$ of the radioactivity of proteins incubated with $\left[2-{ }^{14} \mathrm{C}\right]$ lysine (Pylypets \& Yanovich, 2000). These processes depend on the pathways of introduction of free amino acids in the tissues and are under hormonal control (Bertucci et al., 2019).

This is due to the action of many environmental factors, and requires the rapid extraction of metabolic energy from readily available substrates to ensure the normal functioning of their body (Seibel \& Drazen, 2007).

Tapeworms, including $B$. acheilognathi, do not have a digestive system, they are completely dependent on their feeders, have a labile metabolism depending on environmental conditions, and obtain nutrients, including lipids and proteins, by absorbing them by the entire surface of the strobile (Britton et al., 2011, 2016).

The content of lipids and proteins in the tissues of fish depends on the intensity of their synthesis, as well as the rate of their decomposition. Disorders of lipid and protein synthesis in individual organs affect a number of important processes and functions of the body. In order to determine the causal significance of changes in the content of lipids and proteins in the tissues of this-year carp infected with $B$. acheilognathi, we investigated the intensity of their synthesis in the tissues of uninfected and helminth-infected fish by incubating their sections with glucose and lysine labeled with radioactive carbon, and then determining the radioactivity of the synthesized lipids and proteins. That is why study of the effect of B. acheilognathi invasion of different intensity on the intensity of in vitro lipid and protein synthesis in the tissues of this-year carp using $\left[6-{ }^{14} \mathrm{C}\right]$ glucose and [2$\left.{ }^{14} \mathrm{C}\right]$ lysine as their precursor is relevant not only in terms of basic research, but also in practice and allows research into new drugs and ways to improve the vitality of fish.

\section{Materials and methods}

The study was conducted at the Department of Parasitology and Ichthyopathology of Lviv National University of Veterinary Medicine and
Biotechnologies and the Institute of Animal Biology (Lviv). The object of the study was carp Cyprinus carpio (Linnaeus, 1758) from growing ponds with different intensities of $B$. acheilognathi helminth infestation. For this purpose, three groups of this-year carp were formed. Fish free from intestinal cestodes ( $B$. acheilognathi) were defined as the control group (group I). The fish of group II were weakly infected with helminths (intensity of invasion equaled 1-3 helminths per fish), and group III of fish was highly infected (the invasion intensity was 4 helminths and more per fish). Live weight of the carps ranged 14.5-20.5 g. For the examination, we took the intestinal wall, hepatopancreas and muscle samples of the anterior apical part of the spine, sampled immediately after the decapitation of the fish after they had been caught in the ponds. For biochemical studies, the samples were taken from medium tissue, each of which included a sample of tissues from 6 fish. Four medium samples of fish tissue of each group $(n=4)$ were taken for the examination.

After catching the fish, they had been immediately placed on ice, and the tissues were quickly dissected and frozen in liquid nitrogen. Frozen tissues in a Dewar cryogenic vessel were transported to the laboratory. In the laboratory, the tissue samples were washed with cooled isotonic $\mathrm{NaCl}$ solution, dried with filter paper and kept in $0^{\circ} \mathrm{C}$ until the start of the examination.

The intensity of synthesis of certain classes of $\left[6^{-14} \mathrm{C}\right]$ glucose and $[2-$ $\left.{ }^{14} \mathrm{C}\right]$ lysine lipids in fish tissues was determined in vitro conditions. In order to do this, $100 \mathrm{mg}$ of selected fish tissue were homogenized in a PotterElweim homogenizer in cold Krebs-Ringer phosphate extraction buffer $(\mathrm{pH} 7.4$, ratio of tissue mass to buffer volume was $1: 10 \mathrm{w} / \mathrm{V}) .1 \mu$ Cury $\left[6-{ }^{-14} \mathrm{C}\right]$ glucose or $\left[2-{ }^{14} \mathrm{C}\right]$ lysine were put into the incubation vials and incubated for 60 minutes at $25^{\circ} \mathrm{C}$ in an ultrathermostat (Prohorova, 1982; Vlizlo et al., 2012). After an hour of incubation, $3 \mathrm{~mL}$ of methanol was added to the vials. After $15-30 \mathrm{~min}, 6 \mathrm{~mL}$ of chloroform - methanol mixture (1: 1) had been added to the homogenate, and the contents of the vials were thoroughly mixed. When separating the extraction mixture into phases, $1 \mathrm{~mL}$ of methanol was added. The vials were capped and left at room temperature for $12 \mathrm{~h}$ for lipid extraction. The content of the vials was then filtered through a degreased paper filter, the precipitate was reextracted with $1 \mathrm{~mL}$ of chloroform, and then the extracts were combined. In order to remove water-soluble non-lipid impurities from the extract, $25 \mathrm{~mL}$ of $1 \%$ aqueous KCI solution was added. The content of the tubes were mixed and left for $12 \mathrm{~h}$ until the two-phase system was created. In the lower, chloroform phase, there was a lipid extract, and in the upper - a mixture of methanol, phosphate buffer, KCI solution and soluble nonlipid impurities. The upper phase was sucked out with a water jet pump. The lipid extract was transferred to pre-weighed porcelain cups and evaporated in a fume hood. The cups with lipids were weighed on an analytical scale, and their number was determined by the difference in the weight before and after distillation of the extraction mixture (Folch et al., 1957; Vlizlo et al., 2012).

The content of certain classes of lipids in tissues was determined using thin-layer chromatography on silica gel in an ascending stream of solvents hexane-diethyl ether-glacial acetic acid (70:30 : 1\%) (Kates, 1975; Vlizlo et al., 2012), with subsequent detection of individual classes by treatment of plates in iodine vapour (Stahl, 1965; Vlizlo et al., 2012). Detected spots were pricked with a preparatory needle. Then the lipids with silica gel were transferred into scintillation vials, where $10 \mathrm{~mL}$ of scintillation fluid JS-8 was added (4 $\mathrm{g}$ of 2,5-diphenyloxazole; $0.2 \mathrm{~g}$ of 1,4-di(2)5phenyloxazolyl benzene; $60 \mathrm{~g}$ of naphthalene; $20 \mathrm{~mL}$ of ethylene glycol; $100 \mathrm{~mL}$ of methanol; the total volume of the mixture was adjusted to $1 \mathrm{~L}$ with dioxane). The contents were well mixed. After $24 \mathrm{~h}$, the radioactivity of individual classes of lipids was determined on a liquid scintillation counter (LKB, Sweden) (Prohorova, 1982; Vlizlo et al., 2012).

The intensity of protein synthesis in the tissues in in vitro conditions was investigated by determining the radioactivity of proteins after incubation of the tissue sections with $\left[2-{ }^{14} \mathrm{C}\right]$ lysine and $\left[6-{ }^{14} \mathrm{C}\right]$ glucose. To do this, $100 \mathrm{mg}$ of selected fish tissue was homogenized in a Potter-Elweim homogenizer in cold Krebs-Ringer phosphate extraction buffer $(\mathrm{pH}-7.4$, the ratio of tissue mass to buffer was $1: 10 \mathrm{w} / \mathrm{v}) .1 \mu \mathrm{Curie}$ of $\left[6-{ }^{14} \mathrm{C}\right]$ glucose or $\left[2-{ }^{14} \mathrm{C}\right]$ lysine had been put into the incubation vials and incubated for 60 minutes at $25^{\circ} \mathrm{C}$ in the ultrathermostat with constant stirring (Prohorova, 1982; Vlizlo et al., 2012). Tissue lipids were extracted with a mixture 
of chloroform-methanol $(2: 1)$ using the method of Folch (Folch et al., 1957; Vlizlo et al., 2012). The radioactivity of proteins synthesized by the tissue sections was determined in the delipidated remainder. The proteins were pre-solubilized by treating the tissue sections with hot $5 \mathrm{M} \mathrm{KOH}$ at $70{ }^{\circ} \mathrm{C}$ for four hours. The hydrolyzate was then cooled and neutralized with $5 \mathrm{M}$ of acetic acid solution. The peptides and amino acids that resulted from protein hydrolysis were dissolved in methanol and their radioactivity was determined in liquid scintillation counter LKB (Sweden) in the toluene scintillator JS-8 (Prohorova, 1982; Vlizlo et al., 2012).

All the measures described in this study were carried out in accordance with the European Directive (Directive 2010/63 / EC) on procedures of the protection of animals used for scientific purposes.

The analysis of the obtained data was performed using Statistica 6.0 software (StatSoft Inc., USA). Tables demonstrate the results in the form of $\mathrm{x} \pm \mathrm{SD}$ (standard deviation). Differences between values in the control and experimental groups were determined using ANOVA, where a $\mathrm{P}<$ 0.05 (taking into account correction the Bonferroni) was considered as statistically significant.

\section{Results}

The radioactivity of total lipids synthesized by the sections of the intestinal wall of fish of the 2nd and 3rd groups during incubation with $\left[6-{ }^{14} \mathrm{C}\right]$ glucose was 1.16 and 1.43 times lower respectively $(\mathrm{P}<0.05 ; \mathrm{P}<$ 0.001 ) than during incubation of the sections of the intestinal wall of fish of the 1st group (Fig. 1). These differences were caused by significantly lower radioactivity of all classes of lipids synthesized by sections of the intestinal wall of this year carp of the 3 rd group $(\mathrm{P}<0.05 ; \mathrm{P}<0.001)$ and almost all classes of lipids synthesized by sections of the intestinal wall of this year carp of the 2 nd group $(\mathrm{P}<0.05)$ when incubated with $\left[6-{ }^{14} \mathrm{C}\right]$ glucose, compared with the radioactivity of lipids synthesized by sections of the intestinal wall of fish of the 1st group.

The obtained data demonstrated that the significantly lower lipid content in the tissues of this-year carp infected with $B$. acheilognathi, in par- ticular the intestinal wall, compared with the uninfected ones, was caused by decrease in the intensity of lipid synthesis. This is also indicated by significant decrease in the intensity of synthesis of triacylglycerols, which are reserve lipids, compared with decrease in the intensity of synthesis of structural lipids - phospholipids, cholesterol - in the intestinal wall of thisyear carp infected with $B$. acheilognathi. The examination revealed a decrease in the content of phospholipids and triacylglycerols, which were about $60 \%$ of the total lipid content in the intestinal wall of carp infected with $B$. acheilognathi in comparison to the intestinal wall of uninfected fish. At the same time, there occurs decrease in the intensity of the synthesis of free and esterified cholesterol in the intestinal wall of this-year carp of the 2nd $(\mathrm{P}<0.05)$ and 3rd group infected with $B$. acheilognathi $(\mathrm{P}<$ $0.05 ; \mathrm{P}<0.01)$.

Decrease the contribution of glucose to the substrate provision of lipid synthesis in the tissues of this-year carp infected with $B$. acheilognath $i$ was indicated by significantly lower radioactivity of lipids synthesized by the sections of hepatopancreas of fish of the 2nd and especially 3rd groups during incubation with $\left[6-{ }^{14} \mathrm{C}\right]$ glucose $(\mathrm{P}<0.05 ; \mathrm{P}<0.001)$, compared with the radioactivity of lipids synthesized by the sections of the hepatopancreas of fish of the 1st group (Fig. 2). Similarly as in the wall of the intestine, intensity of synthesis of almost all classes of lipids reliably decreased in the hepatopancreas of this-year carp infected with B. acheilognathi. Moreover, the intensity of the synthesis of structural lipids (phospholipids, cholesterol) was reduced to a much lesser extent than the intensity of the synthesis of reserve lipids (triacylglycerols).

These data show that the lower content of lipids in the hepatopancreas, as well as in the intestinal wall of this year carp from groups II and especially III, compared with the fish of group of group I, was caused by decrease of the intensity of synthesis of lipid from glucose, which is the main precursor of fatty acids and glycerophosphate, which are used in the synthesis of acylglycerols and phospholipids. However, the intensity of cholesterol synthesis and its esterification in the liver, unlike the intestinal wall, of this-year carp infected with $B$. acheilognathi was reduced to a much lesser extent.

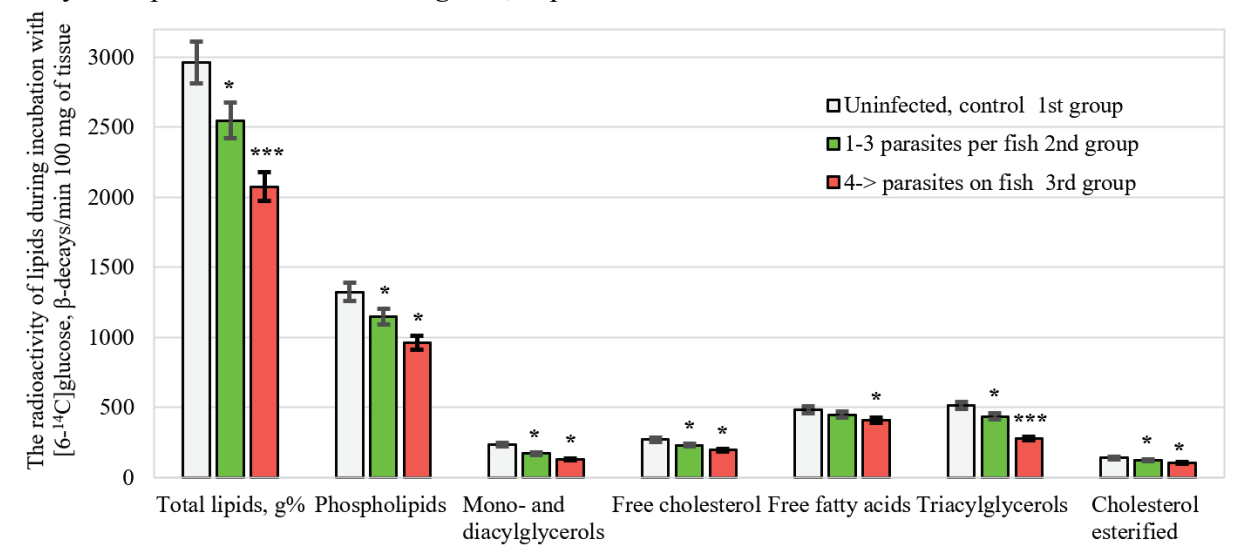

Fig. 1. Radioactivity of lipids synthesized by sections of carp intestines, uninfected and infected with $B$. acheilognathi, during incubation with $\left[6-{ }^{14} \mathrm{C}\right] \mathrm{glu}-$ cose ( $\beta$-decays/min $100 \mathrm{mg}$ tissue, $\mathrm{x} \pm \mathrm{SD}, \mathrm{n}=4)$ : * $-\mathrm{P}<0.05 ; * *-\mathrm{P}<0.01$; *** $-\mathrm{P}<0.001$ relative to controls (including Bonferroni correction)

Data in Figure 3 show that the radioactivity of total lipids synthesized by sections of skeletal muscles of this year carp of the 2nd and 3rd groups during incubation with $\left[6-{ }^{14} \mathrm{C}\right]$ glucose was, respectively, 1.11 and 1.25 times lower $(\mathrm{P}<0.01 ; \mathrm{P}<0.001)$ than the radioactivity of lipids synthesized by the sections of skeletal muscle of 1st group. These data also indicate a decrease in the intensity of synthesis of lipids from glucose in the skeletal muscles of carp infected with B. acheilognathi, but the level of this decrease was less than in the intestinal wall and hepatopancreas. In the skeletal muscles of this-year carp of groups II and III infected with B. acheilognathi, depending on the number of helminths, we observed significant decreases in the intensity of syntheses of triacylglycerol $(\mathrm{P}<$ $0.05 ; \mathrm{P}<0.001)$ and phospholipids $(\mathrm{P}<0.05 ; \mathrm{P}<0.001)$, and a significant difference in the intensity of cholesterol synthesis was found only in the skeletal muscles of fish from group III in comparison with group I.

In general, our results indicate a decrease in the intensity of synthesis of structural and, especially, reserve lipids in the tissues of this-year carp infected with $B$. acheilognathi, as well as dependence of the level of de- crease on the number of B. acheilognathi helminths. These data explain decrease in the intensity of weight (from 5.8 to $14.6 \%$ ) and linear growth, the coefficient of fattening (by 10.7-11.5\%) of this-year carp infected by B. acheilognathi during the growing period compared with uninfected carp.

Data in Figures 1-3 demonstrate not only decrease in the contribution of glucose to the substrate of lipid synthesis in the skeletal muscles of this year carp, but also such of amino acids, particularly lysine. The source of fatty acids that are synthesized in the tissues of animal and used in the synthesis of lipids comprises glucose, ketone bodies and short-chain fatty acids, as well as amino acids. After deamination during lysine catabolism, carbon skeleton of amino acids is converted to acetyl-CoA, which is a precursor of long-chain fatty acids and cholesterol. Therefore, in order to determine the impact of $B$. acheilognathi infection of this year carp on the synthesis of lipids from amino acids occurring in their tissues, we investigated the radioactivity of lipids synthesized by the tissue sections of uninfected and helminth-infected fish during incubation with $\left[2-{ }^{14} \mathrm{C}\right]$ lysine. Data in Figures 4 and 5 shows that the infection of this year carp with 
B. acheilognathi leads to a decrease in the intensity of lipid synthesis in the studied tissues when $\left[2-{ }^{14} \mathrm{C}\right]$ lysine is used as a precursor. In addition, level of this reduction depends on the number of helminths in the intestines of the fish.

Total radioactivity of lipids synthesized by the sections of the intestinal wall of carp of groups II and III during incubation with $\left[2-{ }^{14} \mathrm{C}\right]$ lysine (Fig. 4) was 1.08 and 1.12 times respectively lower $(\mathrm{P}<0.01)$ than the radioactivity of total lipids synthesized by the sections of the intestinal wall of fish of group I. At the same time, during the incubation of the sections of the intestinal wall of this-year carp of group III with $\left[2-{ }^{14} \mathrm{C}\right] \mathrm{lysine}$, com- pared to group I, we observed significantly higher radioactivity of phospholipids, mono-, di- and triacylglycerols and free cholesterol ( $\mathrm{P}<0.05$; $\mathrm{P}<0.01 ; \mathrm{P}<0.001$ ), and during incubation of the sections of the intestinal wall of fish from the II group, there was a significantly higher radioactivity of phospholipids, mono-, di- and triacylglycerols $(\mathrm{P}<0.05)$.

This suggests that infection of this-year carp with $B$. acheilognathi decreases the intensity of synthesis not only of proteins in the intestinal wall, but lipids as well. The level of use of $\left[2-{ }^{14} \mathrm{C}\right]$ lysine for the synthesis of lipids in the intestinal wall was 10 times lower than in protein synthesis.

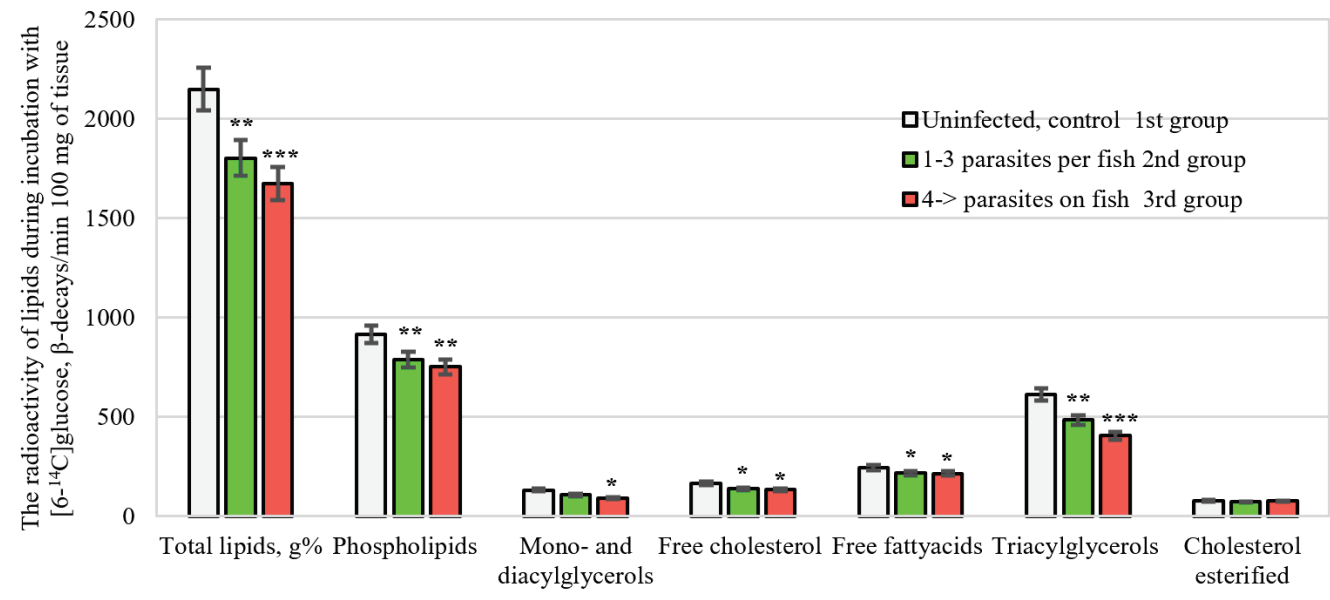

Fig. 2. Radioactivity of lipids synthesized from sections of the hepatopancreas of carp uninfected and infected with B. acheilognathi, during incubation with $\left[6-{ }^{14} \mathrm{C}\right]$ glucose ( $\beta$-decays/min $100 \mathrm{mg}$ tissue, $\mathrm{x} \pm \mathrm{SD}, \mathrm{n}=4$ ): see Fig. 1

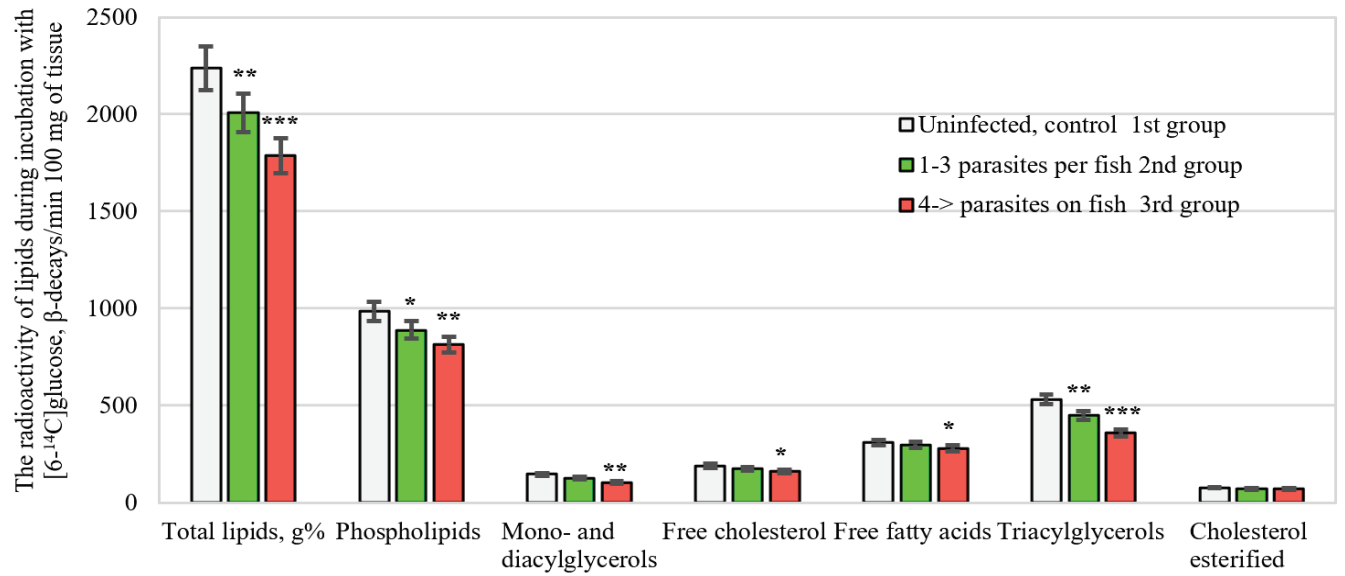

Fig. 3. Radioactivity of lipids synthesized by sections of carp skeletal muscle, uninfected and infected with B. acheilognathi, during incubation with $\left[6-{ }^{14} \mathrm{C}\right]$ glucose ( $\beta$-decays/min $100 \mathrm{mg}$ tissue, $\mathrm{x} \pm \mathrm{SD}, \mathrm{n}=4$ ): see Fig. 1

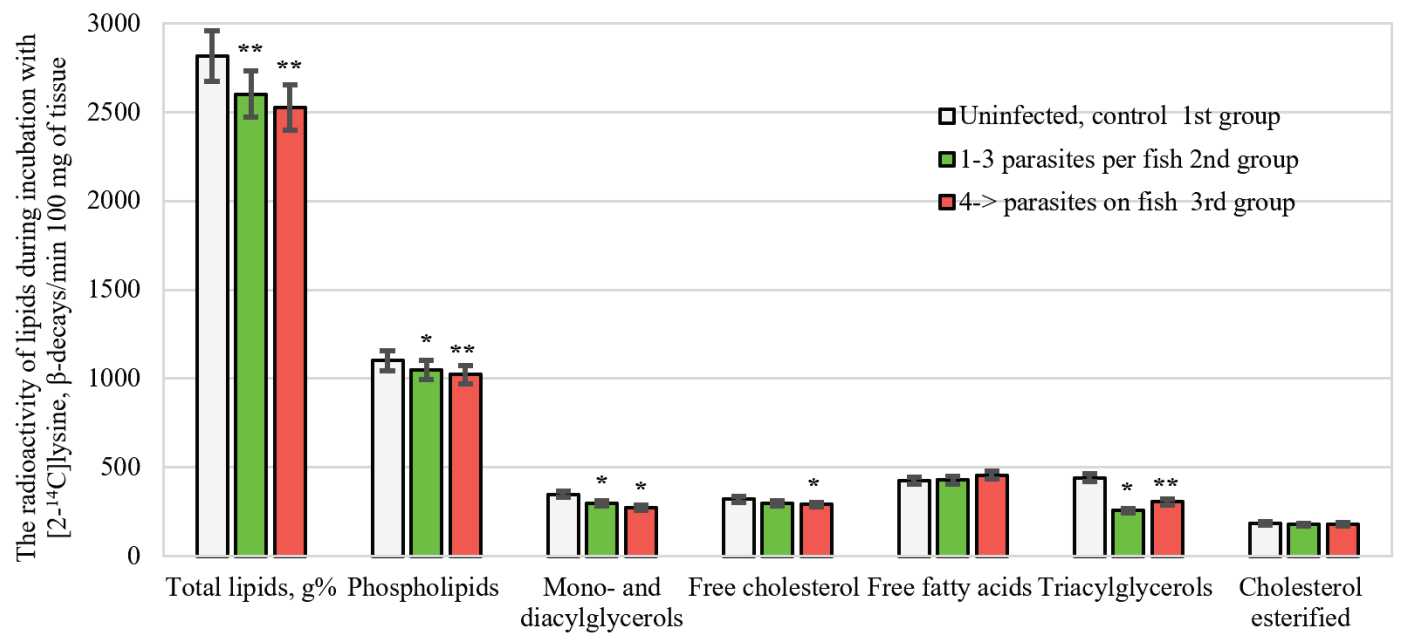

Fig. 4. Radioactivity of lipids synthesized by sections of the intestines of carp uninfected and infected with $B$. acheilognathi, during incubation with $\left[2-{ }^{14} \mathrm{C}\right]$ lysine ( $\beta$-decays/min $100 \mathrm{mg}$ tissue, $\left.\mathrm{x} \pm \mathrm{SD}, \mathrm{n}=4\right)$ : see Fig. 1 
Total radioactivity of lipids synthesized by the sections of the hepatopancreas of this-year carp of groups II and III during incubation with [2${ }^{14} \mathrm{C}$ lysine (Fig. 5) was lower respectively by1.12 and 1.14 times, $(\mathrm{P}<$ $0.01 ; \mathrm{P}<0.001)$ than when incubating the sections of the hepatopancreas of fish of group I. Therefore, the inhibitory effect of the helminth B. acheilognathi on the synthesis of lipids from amino acids in the hepatopancreas is more visible than in the intestinal wall. These differences indicate the vital importance of the hepatopancreas in the catabolism of amino acids in fish, which causes use of their carbon chain in lipid synthesis. Especially decreased was the synthesis of triacylglycerols in the hepatopancreas of this year of carp infected with $B$. acheilognathi - respectively 1.43 and 1.49 times $(\mathrm{P}<0.05 ; \mathrm{P}<0.001)$ in fish of groups II and III in compatison with the 1st group.

The decrease in the intensity of synthesis of phospholipids and cholesterol in the hepatopancreas of carp of groups II and III compared with the synthesis intensity of lipids of those classes in the hepatopancreas from 1 st group was less clearly expressed $(\mathrm{P}<0.05 ; \mathrm{P}<0.01)$ than differences in the intensity of triacylglycerols synthesis.

Thus, under the influence of $B$. acheilognathi, the synthesis of reserve lipids (acylglycerols) in the hepatopancreas of this year carp decreases, and the synthesis of structural lipids (phospholipids, cholesterol) decreases to a lesser extent. In general, our results indicate more intensive synthesis of neutral lipids - acylglycerols and cholesterol in the hepatopancreas of this-year carp than in the intestinal wall. Data on the Figure 6 shows that the radioactivity of total lipids during incubation of the sections of skeletal muscle of this year carp of groups II and III with $\left[2-{ }^{14} \mathrm{C}\right]$ lysine was 1.09 and 1.11 respectively times lower than during incubation of the sections of skeletal muscle of fish of the 1st group $(\mathrm{P}<0.01 ; \mathrm{P}<0.001)$.

The radioactivity of phospholipids synthesized by the sections of this year carp of groups II and III during incubation with $\left[2-{ }^{14} \mathrm{C}\right]$ lysine, compared with the radioactivity of phospholipids synthesized by the sections of skeletal muscle of fish of group I, was lower by 1.05 and 1.10 times $(\mathrm{P}<0.05 ; \mathrm{P}<0.01)$, free cholesterol -1.08 and 1.15 times $(\mathrm{P}>0.05 ; \mathrm{P}<$ $0.05)$, mono- and diacylglycerols -1.14 and 1.33 times $(\mathrm{P}>0.05 ; \mathrm{P}<$ $0.01)$, triacylglycerols -1.19 and 1.37 times $(\mathrm{P}<0.05 ; \mathrm{P}<0.01)$ respectively. It shows that under the influence of the helminth B. acheilognathi, in the skeletal muscles of fish, as well as in other tissues, the intensity of synthesis of reserve lipids (mono-, di- and triacylglycerols) is much lower than the intensity of synthesis of structural lipids (phospholipids, cholesterol). In general, the results indicate that in the tissues of this year carp infected with $B$. acheilognathi, there occurs decrease in the intensity of synthesis of lipids of all classes, especially triacylglycerols, from various substrates - glucose and amino acids, due to a decrease in the number of those substrates.

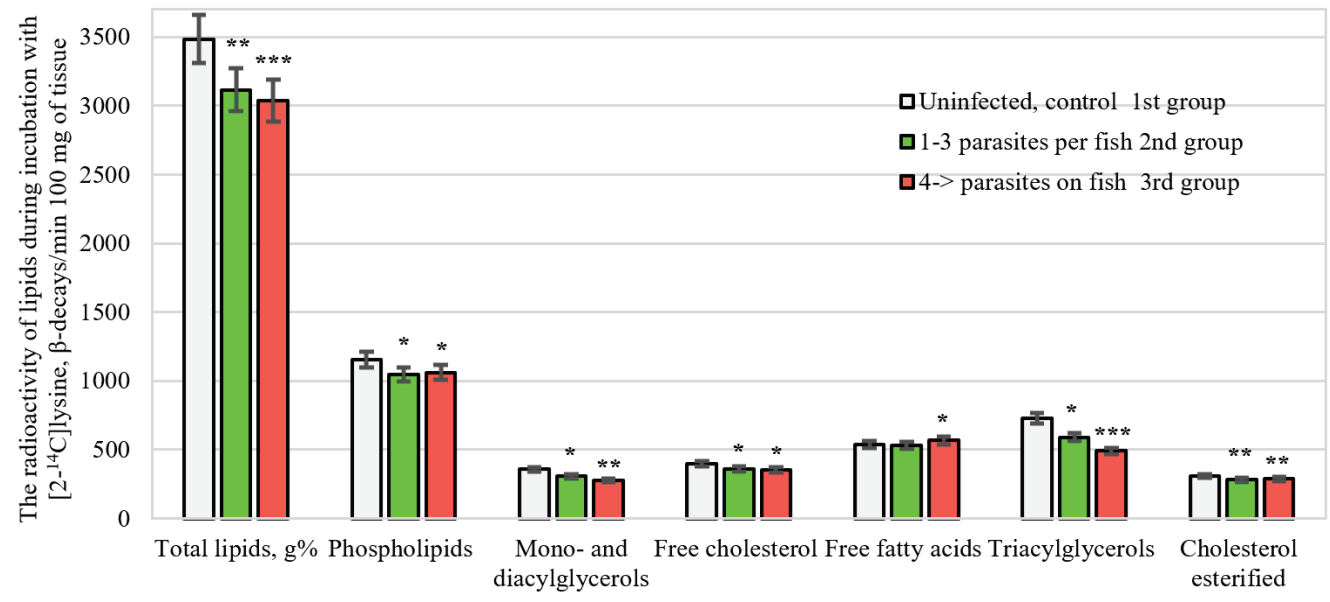

Fig. 5. Radioactivity of lipids synthesized by sections of carp hepatopancreas, uninfected and infected with B. acheilognathi, during incubation with $\left[2-{ }^{14} \mathrm{C}\right]$ lysine ( $\beta$-decays/min $100 \mathrm{mg}$ tissue, $\mathrm{x} \pm \mathrm{SD}, \mathrm{n}=4$ ): see Fig. 1

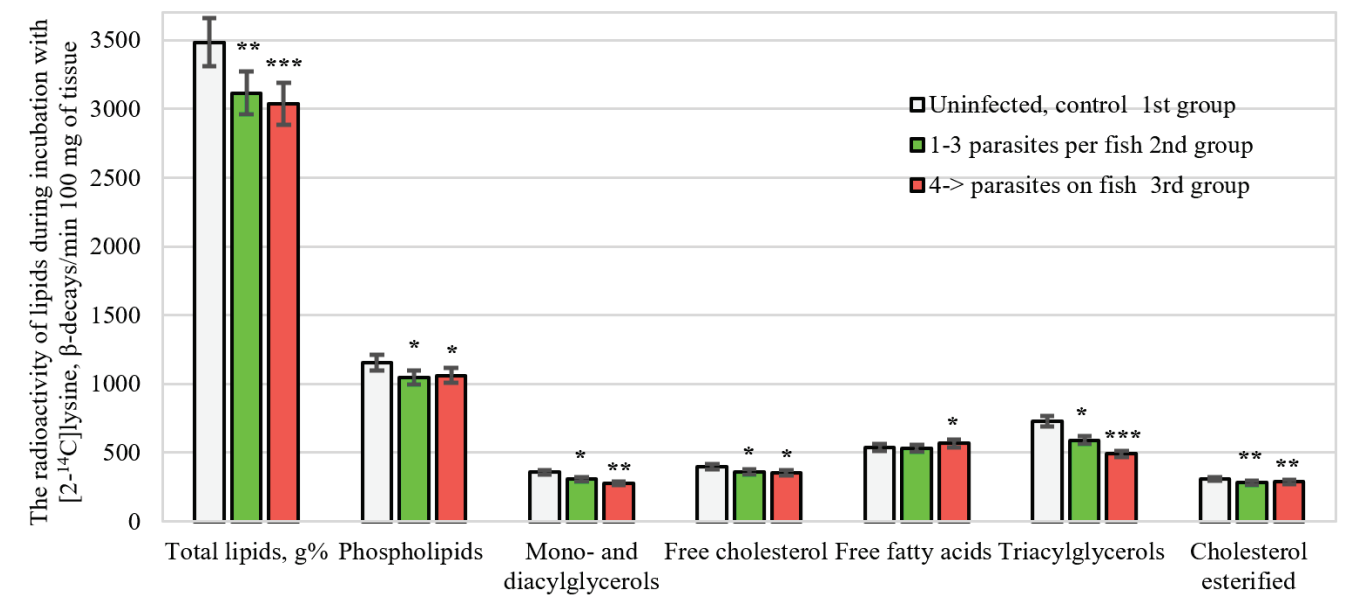

Fig. 6. Radioactivity of lipids synthesized by sections of carp skeletal muscle, uninfected and infected with B. acheilognathi, during incubation with $\left[2-{ }^{14} \mathrm{C}\right] \mathrm{lysine}$ ( $\beta$-decays/min $100 \mathrm{mg}$ tissue, $\mathrm{x} \pm \mathrm{SD}, \mathrm{n}=4$ ): see Fig. 1

Data from Table 1 demonstrate that the radioactivity of proteins synthesized by sections of the studied tissues of this year carp of group III during incubation with $\left[6-{ }^{14} \mathrm{C}\right]$ glucose was reliably higher $(\mathrm{P}<0.05 ; \mathrm{P}<$ 0.01 ) than during incubation with the tissue sections of fish of group I. Differences of a similar direction were found in the radioactivity of proteins synthesized by sections of the studied tissues of this-year carp of group II during incubation with $\left[6-{ }^{14} \mathrm{C}\right]$ glucose compared to the radioactiv- ity of proteins synthesized by the sections of the tissues of fish of group I, but these differences were insignificant in the skeletal muscle. These data indicate an increase in synthesis of amino acids from $\left[6-{ }^{14} \mathrm{C}\right]$ glucose and their use in protein synthesis in the studied tissues of this-year carp during the invasion with $B$. acheilognathi and the dependence of the use level of this substrate on number of helminths. Our research (Table 2) showed that the radioactivity of proteins synthesized by the sections of all studied 
tissues of this-year carp of group III during incubation with $\left[2-{ }^{14} \mathrm{C}\right]$ lysine and radioactivity of proteins synthesized by sections of intestine and hepatopancreas of fish from group II was lower $(\mathrm{P}<0.01-0.05)$ than the radioactivity of proteins synthesized by sections of tissues of the group I. These data indicate an inhibitory effect of $B$. acheilognathi on the intensity of protein synthesis in the tissues of this-year carp accompanied by a decrease in live weight in comparison with the fish from the control group.

\section{Table 1}

Radioactivity of proteins synthesized by sections of carp tissues, uninfected and infected with $B$. acheilognathi, during incubation with $\left[6-{ }^{14} \mathrm{C}\right]$ glucose $(\beta$-decays/min $100 \mathrm{mg}$ tissue, $\mathrm{x} \pm \mathrm{SD}, \mathrm{n}=4)$

\begin{tabular}{lccc}
\hline \multicolumn{1}{c}{ Tissues } & $\begin{array}{c}\text { Uninfected, } \\
\text { control } \\
\text { 1st group }\end{array}$ & $\begin{array}{c}\text { 1-3 parasites } \\
\text { per fish } \\
\text { 2nd group }\end{array}$ & $\begin{array}{c}>3 \text { parasites } \\
\text { on fish }\end{array}$ \\
& 3rd group \\
\hline Intestines & $27624 \pm 1062$ & $30969 \pm 998$ & $32206 \pm 1142^{*}$ \\
Hepatopancreas & $25844 \pm 1112$ & $31984 \pm 1160 * *$ & $33164 \pm 1008^{* *}$ \\
Skeletal muscle & $26248 \pm 1226$ & $28102 \pm 1100$ & $32445 \pm 1094 * *$ \\
\hline
\end{tabular}

Notes: ${ }_{-}-\mathrm{P}<0.05 ; * *-\mathrm{P}<0.01 ; * * *-\mathrm{P}<0.001$

\section{Table 2}

Radioactivity of proteins synthesized by sections of carp tissues, uninfected and infected with $B$. acheilognathi, during incubation with $\left[2{ }^{14} \mathrm{C}\right] \mathrm{lysine}(\beta$-decays/min $100 \mathrm{mg}$ tissue, $\mathrm{x} \pm \mathrm{SD}, \mathrm{n}=4$ )

\begin{tabular}{lcll}
\hline \multicolumn{1}{c}{ Tissues } & $\begin{array}{c}\text { Uninfected, control } \\
\text { 1st group }\end{array}$ & $\begin{array}{c}\text { 1-3 parasites } \\
\text { per fish } \\
\text { 2nd group }\end{array}$ & $\begin{array}{c}>3 \text { parasites } \\
\text { on fish } \\
\text { 3rd group }\end{array}$ \\
\hline Intestines & $24842 \pm 986$ & $20966 \pm 968^{*}$ & $18448 \pm 1143^{* *}$ \\
Hepatopancreas & $26764 \pm 974$ & $23183 \pm 1002^{*}$ & $21012 \pm 1286^{*}$ \\
Skeletal muscle & $22426 \pm 1012$ & $20687 \pm 948$ & $18112 \pm 1102^{*}$ \\
\hline
\end{tabular}

Notes: see Table 1.

Our results indicate a relationship between the intensity of $B$. acheilognathi invasion, on the one hand, and the synthesis and catabolism of amino acids and proteins and the growth rate of carp this year, on the other.

\section{Discussion}

In the conditions of decrease in live weight of carp infected by B. acheilognathi, the deposition of lipids and reserve proteins in the carp tissues significantly reduces, negatively affecting their need for metabolic energy in winter, and thus - their survival (Rehulka et al., 2004; Yuskiv, 2006; Yuskiv \& Yuskiv, 2020). According to some authors (Nanware et al., 2012), the survival of carp largely depends on their total body weight, which is affected the most by the level and quality of feeding and diseases (Rehulka \& Minařik, 2007; Tok et al., 2016).

On the other hand, the impact of $B$. acheilognathi invasion on metabolism and physiological functions of the carp is studied because of insufficient data on physiological and biochemical aspects of pathogenesis of this helminthiasis. There are no data in the literature about the effect of B. acheilognathi on synthetic, energetic and free radical processes in the individual organs and the tissues of carp during different intensities of invasion.

Our research showed that the reason for these changes is a decrease in the intensity of synthesis of protein and lipids in the tissues of carp infected with $B$. acheilognathi due to insufficient provision of their synthesis by, respectively, amino acids on one hand, which resulted by decrease in their intestinal absorption, and also as a result of absorption of amino acids and fatty acids by helminths, which use these substrates in the synthesis of their own proteins and lipids, on the other hand.

Our results show direct relationship between the intensity of $B$. acheilognathi infection and a decrease in the intensity of protein and lipid synthesis in carp tissues. In particular, in the conditions of infection of carp in the amount of 1-3 parasites per fish, the intensity of protein synthesis in the intestinal wall, hepatopancreas and skeletal muscle was lower by 1.18 , 1.15 and 1.08 times respectively, the intensity of lipid synthesis - lower by $1.08,1.12$ and 1.09 times, compared with their content in these tissues of uninfected fish (control); however, almost all the differences in the studied parameters were unreliable. The intensity of protein synthesis in the intes- tinal wall, hepatopancreas and skeletal muscles of fish infected with four or more B. acheilognathi parasites per individual, compared with the intensity of their synthesis in these tissues of uninfected fish, was lower by $1.35,1.27$ and 1.24 times respectively, the intensity of lipid synthesis $1.11,1.15$ and 1.16 times, and all differences in the intensity of protein and lipid synthesis in the tissues of fish of the experimental groups, compared with the fish of the control group, were significant. The reason for this may be the fact that helminths use parts of metabolites formed by the breakdown of nutrients of the food consumed by fish in their synthetic and energetic processes. This conclusion is coherent with the data we obtained about the direct relationship between the intensity of lipid synthesis in the intestinal wall of this year carp infected with $B$. acheilognathi and the number of helminths, as well as a similar relationship between the intensity of protein synthesis in the intestinal wall and the number of helminths in infected fish. These data indicate the negative impact of infection of carp with large numbers of $B$. acheilognathi on the synthesis of proteins and lipids in fish, on the main processes that underlie their activities, including the growth process.

The obtained data confirms the opinion (Coop \& Holmens, 1996; Kovalenko et al., 2019) that parasites can significantly affect the feeding processes of the host, limiting its ability to consume food. This is an important factor in the deterioration of the host's nutrition, which is directly related to the catalytic ability of enzymes in its intestines (Britton et al., 2011; Bar \& Volkoff, 2012).

It was found that during short-term adaptation to lowered temperatures, the synthesis and the content of phospholipids and cholesterol in the tissue of fish rises and that, on the contrary, their content decreases during adaptation to raised temperatures (Tocher, 2010; He et al., 2015). The important role of phospholipids and cholesterol in the processes of temperature adaptation in poikilothermic animals is confirmed by the fact that feeding fish food with high content of phospholipids and cholesterol increases their resistance to low temperatures (Tocher, 2010; Tocher \& Glencross, 2015). Our data supports this conclusion, as evidenced by the detected significantly lower radioactivity of phospholipids and triacylglycerols during incubation of the tissue sections of carp infected with B. acheilognathi with all studied precursors $-\left[6-{ }^{14} \mathrm{C}\right]$ glucose and $\left[2-{ }^{14} \mathrm{C}\right] \mathrm{ly}-$ sine - than when incubating the sections of uninfected fish. The decrease of intensity of synthesis of these classes of lipids, the content of which in the tissues of this-year carp was approximately $60 \%$ of the total lipid content, was caused by the complex action of several factors found in helminth-infected fish. The first of these factors is the deficiency of free fatty acids in the intracellular fundus of tissues of fish infected with B. acheilognathi (Yuskiv \& Yuskiv, 2020).

Polyunsaturated fatty acids are known to be essential components of glycerophospholipids, and a decrease of their content in the intracellular fund may cause a decrease in their synthesis. The second factor that causes a decrease in phospholipids and triacylglycerols in the tissues of infected by $B$. acheilognathi fish is a decrease in glycerol phosphate production due to decreased glucose metabolism (Tocher \& Sargent, 1990; Wang et al., 2018).

The third factor that influences the synthesis of triacylglycerols in carp tissues infected by $B$. acheilognathi may be insufficient production of ATP, which ensures the use of fatty acids in the acylation processes in the synthesis of triacylglycerols. This is evidenced by the significantly higher content of monoacylglycerols and diacylglycerols in the tissues of fish infected with B. acheilognathi than in the tissues of healthy fish (Yuskiv \& Yuskiv, 2020).

The negative impact of $B$. acheilognathi on the life of carp occurs through disorders of lipid metabolism in their body: reduced synthesis of structural lipids, which negatively affects their growth; reduction of triacylglycerol reserves in the fish tissues, which negatively affects their need for metabolic energy in winter; impaired absorption of lipids in the intestine due to a decrease in the production of phospholipids that are part of the bile, which is important in the emulsification of lipids during their absorption (Romano et al., 2020).

The decrease in the content of structural and reserve lipids in carp tissues during infection with $B$. acheilognathi is caused by decrease in the intensity of their synthesis using all the studied precursors $-\left[6-{ }^{14} \mathrm{C}\right]$ glucose and $\left[2-{ }^{14} \mathrm{C}\right]$ lysine. This data also indicates insufficient substrate support for 
lipid synthesis in the tissues of this year carp during infection with B. acheilognathi due to reduced absorption of nutrients and their conversion in fish tissues into lipid precursors. It is known that glucose is a precursor of acetyl-CoA, which is a precursor of fatty acids and cholesterol and glycerol phosphate used in the synthesis of acylglycerols and glycerophospholipids (Hemre et al., 2002; Vargas-Chacoff et al., 2016; Michelle et al., 2017). However, the source of fatty acids used in the synthesis of lipids in fish tissues comprises fatty acids of feed lipids, which after the breakdown of lipids in the intestines of fish are added to the general fund of fatty acids in their body (Kersten, 2001). Amino acids are used in the synthesis of fatty acids after the conversion of their carbon chain into acetyl-CoA (Britton et al., 2011; Michelle et al., 2017).

Infection of fish with $B$. acheilognathi causes an increase in the intensity of synthesis processes from various precursors, which are formed as a result of glucose metabolism. This is evidenced by the higher radioactivity of proteins synthesized by tissue sections of carp infected with $B$. acheilognathi when incubated with $\left[6-{ }^{14} \mathrm{C}\right] \mathrm{glucose}$, compared with the radioactivity of proteins synthesized by tissue homogenates of uninfected carp. It is known that in the process of glucose metabolism in animal tissues, there develops pyruvic acid, from which alanine is formed by reamination with glutamic acid, which is a donor of an amino group in the synthesis of various substituted amino acids (Rui, 2014). In addition, hepatocytes have a great ability to choose the source of metabolic energy (glucose or fatty acids). This choice is regulated by both nutritional and hormonal signals. Glycolysis is dominant in the state of feeding at high glucose levels. Glycolysis intermediates are used for the synthesis of lipids, amino acids and other important molecules, as well as for complete oxidation in order to form ATP. In the state of hunger, in which glucose levels are low, hepatocytes switch to $\beta$-oxidation of fatty acids to provide metabolic energy (Rui, 2014).

The limiting role of lysine for the diet of fish is mainly due to its intensive use in the synthesis of tissue proteins, and the role of sulfur-containing amino acids is associated with their significant catabolism. It was found that when incubating sections of carp skeletal muscle with $\left[2-{ }^{14} \mathrm{C}\right]$ lysine, the total level of radioactivity of proteins, lipids and $\mathrm{CO}_{2}$ was significantly higher than when incubating fish muscles with $\left[2-{ }^{14} \mathrm{C}\right]$ cystine and $3-$ phenyl-[1- $\left.{ }^{14} \mathrm{C}\right]$ alanine (Hrekh et al., 2001).

The deficiency of essential amino acids in the body of this-year carp infected with $B$. acheilognathi indicates a decrease in lysine in total proteins in their tissues. Along with the usage of lysine in the synthesis of proteins in fish tissues, part of it in the cell goes into the catabolic fund, and the carbon skeleton of the amino acid after deamination converts into acetyl-CoA, which is used in the synthesis of fatty acids and cholesterol on one hand, and is oxidized in the tricarboxylic acid cycle on the other hand (Albaugh et al., 2010; Nelson, 2016).

The amount of protein in the dry matter of fish tissues at different stages of the life cycle is $45-75 \%$ and is therefore necessary for the synthesis of new tissues. Fish obtain protein from their food and synthesis of their own protein is insignificant (NRC, 1993). The rate of protein synthesis is mainly achieved by providing sufficient energy and amino acids (Storch \& Pörtner, 2003). Part of the metabolic processes in muscles receives more than half of the ATP formed aerobically. Therefore, the level of aerobic metabolism is one of the factors that determine the intensity of protein synthesis in muscle tissue (Goolish, 1991; Sebert et al., 2011).

Our results unequivocally prove that the parasite $B$. acheilognathi, which adapted to the intestinal conditions of carp, significantly affects the feeding processes of the host depending on the intensity of helminth infestation, which is accompanied by impairment of the synthesis of lipids and proteins in the intestinal wall hepatopancreas, skeletal muscle, and is evidence of the disturbance of the course of metabolic processes in the carp organism.

\section{Conclusion}

During the infection of carp by the helminth B. acheilognathi, the intensity of lipid synthesis in the intestinal wall, hepatopancreas, skeletal muscle of this-year carp in vitro when $\left[6-{ }^{14} \mathrm{C}\right]$ glucose is used as a precursor was much lower than when $\left[2-{ }^{14} \mathrm{C}\right]$ lysine was used as a precursor. In the studied tissues, the synthesis of reserve lipids (mono-, di- and tri- acylglycerols) was significantly more reduced compared with structural ones (phospholipids and cholesterol), which depended on the intensity of the invasion of $B$. acheilognathi. In metabolic processes in the intestinal wall, hepatopancreas, skeletal muscles of this-year carp in in vitro conditions, $\left[6-{ }^{14} \mathrm{C}\right]$ glucose was used much more than $\left[2-{ }^{14} \mathrm{C}\right]$ lysine during infection with $B$. acheilognathi helminth.

The intensity of protein synthesis in in vitro conditions in the intestinal wall, hepatopancreas, skeletal muscle of this-year carp during the infection with helminth $B$. acheilognathi, increased on average from $7.1 \%$ to $28.3 \%$ when $\left[6-{ }^{14} \mathrm{C}\right]$ glucose was added to the incubation medium and decreased on average from $25.7 \%$ to $7.8 \%$ when $\left[2-{ }^{14} \mathrm{C}\right]$ lysine was added.

\section{References}

Ahmad, F., Fazili, K. M., Sof, O. M., Sheikh, B. A., \& Sof, T. A. (2018). Distribución y patología causada por Bothriocephalus acheilognathi, Yamaguti 1934 (Cestoda: Bothriocephalidae). Revisión bibliográfica. Revista Veterinaria, 29(2), 142-149.

Albaugh, B. N., Arnold, K. M., \& Denu, J. M. (2010). KAT(ching) metabolism by the tail: Insight into the links between lysine acetyltransferases and metabolism. ChemBioChem, 12(2), 290-298.

Al-Niaeemi, B. H., \& Dawood, M. H. (2017). Total lipids estimation and fatty acids analysis of Bothriocephalus acheilognathi, a parasitic tapeworm of the common carp (Cyprinus carpio L., 1758) from Tigris river-Mosul city. World Journal of Pharmacy and Pharmaceutical Sciences, 6(9), 1641-1651.

Bar, N., \& Volkoff, H. (2012). Adaptation of the physiological, endocrine, and digestive system functions to prolonged food deprivation in fish. In: McCue, M. D. (Ed.). Comparative physiology of fasting, starvation, and food limitation. Springer, Heidelberg. Pp. 69-89.

Bertucci, J. I., Blanco, A. M., Sundarrajan, L., Rajeswari, J. J., Velasco, C., \& Unniappan, S. (2019). Nutrient regulation of endocrine factors influencing feeding and growth in fish. Frontiers in Endocrinology, 2019, 10.

Britton, J. R., \& Andreou, D. (2016). Parasitism as a driver of trophic niche specialisation. Trends in Parasitology, 32(6), 437-445.

Britton, J. R., Pegg, J., \& Williams, C. F. (2011). Pathological and ecological host consequences of infection by an introduced fish parasite. PLoS One, 6(10), e26365.

Conde-Sieira, M., \& Soengas, J. L. (2017). Nutrient sensing systems in fish: Impact on food intake regulation and energy homeostasis. Frontiers in Neuroscience, 2017, 10 .

Coop, R. L., \& Holmes, P. H. (1996). Nutrition and parasite interaction. International Journal for Parasitology, 26, 951-962.

Deb, A. C. (2011). Fundamentals of biochemistry. New Central Book Agency Ltd., London.

Dogan, G. (2008). Protein metabolism in fishes. Journal of Fisheries, 2(1), 30-40.

Fernandes, T., \& McMeans, B. C. (2019). Coping with the cold: Energy storage strategies for surviving winter in freshwater fish. Ecography, 42(12), 2037-2052.

Folch, J., Lees, M., \& Stanley, G. H. S. (1957). A simple method for the isolation and purification of total lipides from animal tissues. Journal of Biological Chemistry, 226(1), 497-509.

Gilannejad, N., Martínez-Rodríguez, G., Yúfera, M., \& Moyano, F. J. (2018). Modelling digestive hydrolysis of nutrients in fish using factorial designs and desirability function. PLoS One, 13(11), e0206556.

Goolish, E. M. (1991). Aerobic and anaerobic scaling in fish. Biological Reviews, 66(1), 33-56.

He, A.-Y., Ning, L.-J., Chen, L.-Q., Chen, Y.-L., Xing, Q., Li, J.-M., Qiao, F., Li, D.L., Zhang, M.-L.,\& Du, Z.-Y. (2015). Systemic adaptation of lipid metabolism in response to low- and high-fat diet in Nile tilapia (Oreochromis niloticus). Physiological Reports, 3(8), e12485.

Hemre, G.-I., Mommsen, T. P., \& Krogdahl, Å. (2002). Carbohydrates in fish nutrition: Effects on growth, glucose metabolism and hepatic enzymes. Aquaculture Nutrition, 8(3), 175-194.

Hrekh, V. I., Blaha, N. A., Dobryanska, H. M., Shemchuk, V. R., Kornyat, S. B., \& Yanovich, V. G. (2001). Metabolizm $\left[2-{ }^{14} \mathrm{C}\right] \mathrm{lizynu},\left[2-{ }^{14} \mathrm{C}\right]$ tsystynu i 3-fenil-[1$\left.{ }^{14} \mathrm{C}\right]$ alaninu u skeletnykh myazakh koropa $\mathrm{v}$ umovakh in vitro [Metabolism of $\left[2-{ }^{14} \mathrm{C}\right]$ lysine, $\left[2-{ }^{14} \mathrm{C}\right]$ cystine and 3-phenyl- $\left[1-{ }^{14} \mathrm{C}\right]$ alanine in carp skeletal muscle in vitro]. The Animal Biology, 3(1), 88-91 (in Ukrainian).

Hrytsyniak, I. I., Smolianinov, K. B., \& Yanovich, V. G. (2010). Obmin lipidiv u ryb [Lipid metabolism in fish]. Triad Plus, Lviv (in Ukrainian).

Kates, M. (1975). Technika lipidologii. Vidilenie, analis i indentifikatsia lipidov [Technique of lipidology. Isolation, analysis and identification of lipids]. Peace, Moscow (in Russian).

Kaushik, S. J., \& Seiliez, I. (2010). Protein and amino acid nutrition and metabolism in fish: Current knowledge and future needs. Aquaculture Research, 41(3), 322-332.

Kersten, S. (2001). Mechanisms of nutritional and hormonal regulation of lipogenesis. EMBO Reports, 2(4), 282-286. 
Kovalenko, J., Shlapak, O., Potrokhov, A., \& Zin'kovskiy, O. (2019). Effect of antropogenic pollution on physiological and biochemical parameters of fish and composition of their parasitocenoses. Fisheries Science of Ukraine, 49, 72-88.

Kuchta, R., Choudhury, A., \& Scholz, T. (2018). Asian fish tapeworm: The most successful invasive parasite in freshwaters. Trends in Parasitology, 34(6), 511-523.

Kuchta, R., Scholz, T., \& Bray, R. A. (2008). Revision of the order Bothriocephalidea Kuchta, Scholz, Brabec \& Bray, 2008 (Eucestoda) with amended generic diagnoses and keys to families and genera. Systematic Parasitology, 71(2), 81-136.

Kurovskaya, L., \& Stril'ko, G. (2016). Effect of aquatic environment ph on the leve of ectoparasite infestation, protein and lysozym content in some cyprinid species. Fisheries Science of Ukraine, 35, 88-101.

Li, P., Mai, K., Trushenski, J., \& Wu, G. (2008). New developments in fish amino acid nutrition: Towards functional and environmentally oriented aquafeeds. Amino Acids, 37(1), 43-53.

Meyer-Burgdorff, K.-H., \& Rosenow, H. (1995). Protein turnover and energy metabolism in growing carp. Journal of Animal Physiology and Animal Nutrition, $73,113-122$

Nanware, S. S., Nazneen, U., Bhure, D. B., \& Garad, V. B. (2012). Studies on protein content of cestode Cotugnia and its host Gallus gallus domesticus. Joumal of Experimental Sciences, 3(1), 40-41.

National Research Council (NRC). (1993). Nutrient Requirements of Fish. National Academy Press, Washington.

Nelson, J. A. (2016). Oxygen consumption rate v. rate of energy utilization of fishes: A comparison and brief history of the two measurements. Journal of Fish Biology, 88(1), 10-25.

Pastorino, P., Bertoli, M., Kušće, M., Giulianini, P. G., Menconi, V., Prearo, M., \& Pizzul, E. (2020). Liver lipid accumulation in European Bullhead (Cottus cobio) from a High-Mountain Lake: An adaptive strategy to survive the adverse winter season. Diversity, 12(12), 442.

Prohorova, M. I. (1982). Metody biohimicheskih issledovanij (lipidnyj i energeticheskij obmen) [Methods of biochemical research (lipid and energy metabolism)]. Leningrad University Press, Leningrad (in Russian).

Pylypets, A. Z., \& Yanovich, V. G. (2000). Vykorystannia $\left[6-{ }^{14}\right.$ C]hliukozy, [1$\left.{ }^{14} \mathrm{C}\right]$ palmitynovoi kysloty i $\left[2-{ }^{14} \mathrm{C}\right]$ lizynu v enerhetychnykh protsesakh u skeletnykh miazakh koropa riznoho viku v umovakh in vitro [Use of $\left[6-{ }^{14} \mathrm{C}\right]$ glucose, $\left[1-{ }^{14} \mathrm{C}\right]$ palmitic acid and $\left[2-{ }^{14} \mathrm{C}\right]$ lysine in energy processes in skeletal muscles of carp of different ages in vitro]. Scientific and Technical Bulletin of the Institute of Animal Biology Lviv, 2, 79-81 (in Ukrainian).

Řehulka, J., \& Minařik, B. (2007). Blood parameters in brook trout Salvelinus fontinalis (Mitchill, 1815), affected by columnaris disease. Aquaculture Research, 38(11), 1182-1197.

Rehulka, J., Minarik, B., Adamec, V., \& Rehulkova, E. (2005). Investigations of physiological and pathological levels of total plasma protein in rainbow trout, Oncorhynchus mykiss (Walbaum). Aquaculture Research, 36(1), 22-32.

Romano, N., Kumar, V., Yang, G., Kajbaf, K., Rubio, M. B., Overturf, K., Brezas, A., \& Hardy, R. (2020). Bile acid metabolism in fish: Disturbances caused by fishmeal alternatives and some mitigating effects from dietary bile inclusions. Reviews in Aquaculture, 12(3), 1792-1817.

Rui, L. (2014). Energy metabolism in the liver. Comprehensive Physiology, 4, 177-197.

Scholz, T., Kuchta, R., \& Williams, C. (2012). Bothriocephalus acheilognathi. In: Patrick, T. K. W., \& Buchmann, K. (Eds.). Fish Parasites: Pathobiology and Protection. CABI Publishing. Pp. 282-297.

Schutz, Y. (2011). Protein turnover, ureagenesis and gluconeogenesis. International Journal for Vitamin and Nutrition Research, 81(23), 101-107.

Sébert, P., Mortelette, H., Nicolas, J., Amérand, A., Belhomme, M., \& Moisan, C. (2011). In vitro aerobic and anaerobic muscle capacities in the European eel,
Anguilla anguilla: Effects of a swimming session. Respiratory Physiology and Neurobiology, 176(3), 118-122.

Seibel, B. A., \& Drazen, J. C. (2007). The rate of metabolism in marine animals: Environmental constraints, ecological demands and energetic opportunities. Philosophical Transactions of the Royal Society B: Biological Sciences, 362(1487), 2061-2078.

Sheridan, M. A. (1988). Lipid dynamics in fish: Aspects of absorption, transportation, deposition and mobilization. Comparative Biochemistry and Physiology Part B: Comparative Biochemistry, 90(4), 679-690.

Shimeno, S., Kheyyali, D., \& Takeda, M. (1990). Metabolic adaptation to prolonged starvation of carp. Nippon Suisan Gakkaishi, 56(1), 35-41.

Stahl, E. (1965). Chromatografia v tonkih sloyah [Chromatography in thin layers]. Peace, Moscow (in Russian).

Storch, D., \& Pörtner, H. O. (2003). The protein synthesis machinery operates at the same expense in eurythermal and cold stenothermal pectinids. Physiological and Biochemical Zoology, 76(1), $28-40$.

Tao, Y.-F., Qiang, J., Bao, J.-W., Chen, D.-J., Yin, G.-J., Xu, P., \& Zhu, H.-J. (2018). Changes in physiological parameters, lipid metabolism, and expression of microRNAs in genetically improved farmed tilapia (Oreochromis niloticus) with fatty liver induced by a high-fat diet. Frontiers in Physiology, 9, 1521.

Tocher, D. R. (2010). Fatty acid requirements in ontogeny of marine and freshwater fish. Aquaculture Research, 41(5), 717-732.

Tocher, D. R., \& Glencross, B. D. (2015). Lipids and fatty acids. In: Lee, C.-S., Lim, C., Gatlin, D. M., \& Webster, C. D. (Eds.). Dietary nutrients, additives, and fish health. Wiley-Blackwell, Canada. Pp. 47-94.

Tocher, D. R., \& Sargent, J. R. (1990). Incorporation into phospholipid classes and metabolism via desaturation and elongation of various ${ }^{14} \mathrm{C}$-labelled (n-3) and (n$6)$ polyunsaturated fatty acids in trout astrocytes in primary culture. Journal of Neurochemistry, 54(6), 2118-2124.

Tok, N. C., Jain, K. K., Prabu, D. L., Sahu, N. P., Munilkumar, S., Pal, A. K., Siddiah, G. M., \& Kumar, P. (2016). Metabolic and digestive enzyme activity of Pangasianodon hypophthalmus (Sauvage, 1878) fingerlings in response to alternate feeding of different protein levels in the diet. Aquaculture Research, 48(6), 2895-2911.

Vargas-Chacoff, L., Muñoz, J. L. P., Hawes, C., Oyarzún, R., Pontigo, J. P., Saravia, J., González, M. P., Morera, F. J., Labbé, B. S., Bertrán, C., Mardones, O., Pino, J., \& Wadsworth, S. (2016). Atlantic salmon (Salmo salar) and Coho salmon (Oncorhynchus kisutch) display differential metabolic changes in response to infestation by the ectoparasite Caligus rogercressevi. Aquaculture, 464, 469-479.

Vlizlo, V. V., Fedoruk, R. S., \& Ratych, I. B. (2012). Laboratorni metody doslidzhen' u biolohiji, tvarynnytstvi ta veterynarnij medytsyni [Laboratory methods in biology, animal husbandry and veterinary medicine]. Spolom, Lviv (in Ukrainian).

Wang, J., Liang, X.-F., He, S., Li, J., Huang, K., Zhang, Y.-P., \& Huang, D. (2018). Lipid deposition pattern and adaptive strategy in response to dietary fat in Chinese perch (Siniperca chuatsi). Nutrition and Metabolism, 15, 77.

Yuskiv, I. D. (2006). Morfometrychni ta fiziolohichni pokaznyky rostu koropa pry Botriotsefalozniy invazii [Morphometric and physiological indicators of carp growth during Botriocephalus invasion]. Scientific Bulletin of the Lviv National Academy of Veterinary Medicine S. Z. Gzhytskyi, Lviv, 8(2), 224-229 (in Ukrainian).

Yuskiv, L. L., \& Yuskiv, I. D. (2020). The lipid metabolism in carp during invasion by the tapewom Bothriocephalus acheilognathi. Regulatory Mechanisms in Biosystems, 11(2), 214-219. 